\title{
AFRICAN AMERICAN/BLACK VOTERS IN MICHIGAN WANT TO SAVE
}

\section{African American/Black Voters Support a Retirement Savings Option}

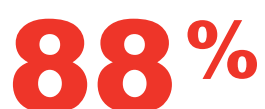

agree that Michigan policymakers should make it easier for all workers to save for retirement out of their regular paycheck.

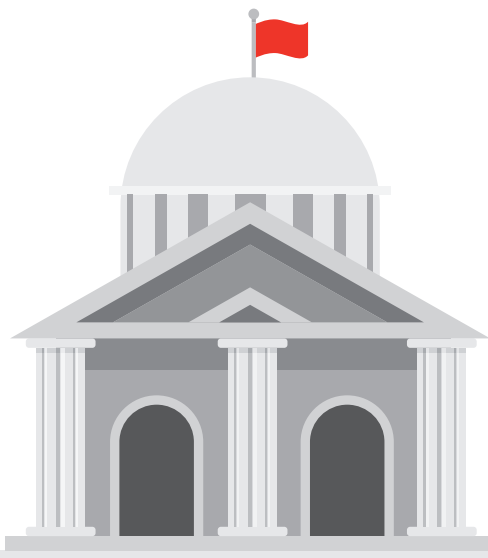

$90 \%$

$83 \%$

Democrats Independents

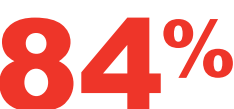

believe it is very important to be able to save for retirement at work.

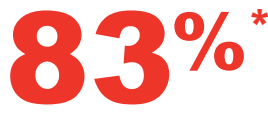

of workers without access

to a workplace savings program would take advantage of one if it were available.

\section{African American/Black Voters in Michigan are Anxious About Retirement}

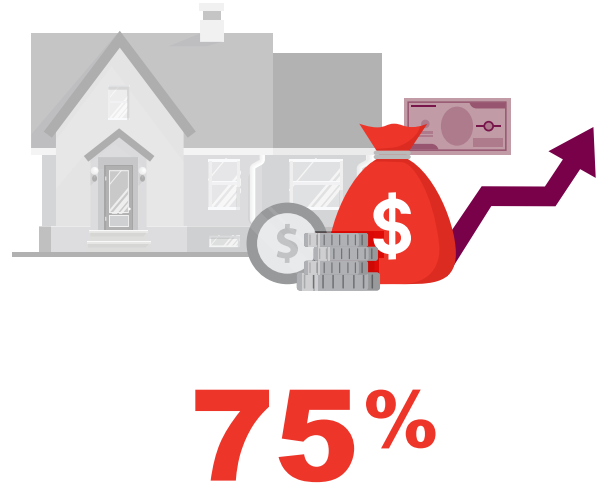

are concerned that increases in their cost of living expenses will reduce their standard of living in retirement.
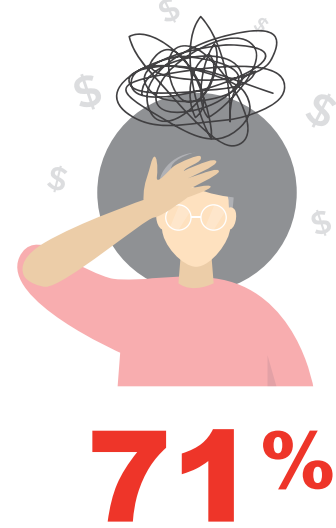

feel anxious about having enough money for retirement.
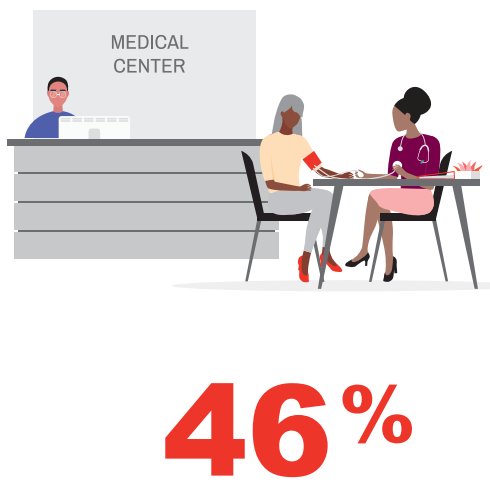

are not confident that they will be able to cover healthcare expenses

in their retirement years.
*Note: Small base. Use caution when generalizing to the larger African American/Black population in Michigan. www.aarp.org/miretirement

200 interviews with African American/Black registered voters in Michigan C2021 AARP ALL RIGHTS RESERVED
Contact Us: Lona Choi-Allum // LAllum@aarp.org // AARP Research Lisa Dedden Cooper // LCooper@aarp.org //AARP Michigan https://doi.org/10.26419/res.00460.007 